\title{
Evaluation of Public Special School Environment (case: SLB Negeri Ungaran)
}

\author{
Bangun I.R. Harsritanto*, Dessy Oktavia, Mira Annisa Rezeki, Hermin Werdiningsih \\ Architecture Department, Engineering Faculty, Universitas Diponegoro, Semarang, Indonesia
}

\begin{abstract}
Information of design standard often become debatable condition in construction process. That condition brought different performance of building especially public building such public special schools. This paper aimed to emphasize the design regulation on special school by evaluating a public special school in Semarang Regency SLB Negeri Ungaran. The standard of education building standard of PERMENDIKNAS RI No. $33 / 2008$ was being resumed into design criteria, then it became the evaluation sheet to value the case. The result of this research shown that most of the mandatory space already being built but the details were not designed as the standards.
\end{abstract}

\section{Introduction}

Education is a human right which being mandated on Indonesia's basic constitution UUD 1945 verse 31 (1) as mentioned that "every citizen have right in education" [1]. Every citizen as described before also included the people with disabilities. The derivates constitution was published on regulation UU no 20/2003 verse 5 (2) which said "every citizen with physical, mental, emotional, social disabilities have right to study on special education facilities" [2].

However, we found citizen with disabilities with no proper education of 12 years mandatory basic education in the real condition. Indonesia citizen with disabilities estimated $12.5 \%$ of all citizen but $45.57 \%$ of them were never graduated from elementary school $[3,4]$. Data of 14 Indonesia provinces shown that $60 \%$ of student age citizen with disabilities were not schooled [5]. The biggest problem for citizen with disabilities in gaining education is no open access for them to study in special education facilities [6].

Indonesia has more than 4929 special schools from kindergarten until high school grade with 28914 class on them [7]. But $73 \%$ of students were studied in private school and the remain $27 \%$ attended the public school [8]. This condition indicated that government/public schools were not provided the good performance in serving the citizen with disabilities [9]. Nowadays the ministry of education has planned to build 25 until 30 special schools in a year to serve national education for all citizens [10]. Furthermore, the demand of quantities in every city/regency is more than a special school with its facilities shall be the national priority, since some region has very large population and coverage area [11].

Above situation brought a massive construction in special education facilities in every region in Indonesia [12]. However, the mass production often not followed by proper

* Corresponding author : bangunirh $@$ arsitektur.undip.ac.id 
qualities in construction [13]. Until today, Indonesia has set national standard in education facilities on Ministry of education decree no.33/2008 about special school (SLB) design standard (Indonesia: permendiknas No. 33 Tahun 2008 tentang Standar Sarana dan Prasarana Sekolah Dasar Luar Biasa, Sekolah Menengah Pertama Luar Biasa, dan Sekolah Menengah atas Luar Biasa SMALB). The national standard has already set for 12 years but the realisation is still in progress.

Ungaran is a regency next to the Central Java Capitol City, Semarang. This area is rurban (rural urban area) which still developing it infrastructure to match the region aims. One of the infrastructures is education facilities and special education which is the main subject for this research. SLB Negeri Ungaran is Public Special School which built and fully supported by government to give education to the student with disabilities and special needs in Ungaran.

This research purpose is to resumed an evaluation sheet of special school design guideline then to evaluate SLB Negeri Ungaran as a case study. This evaluation sheet was set from the ministry of education regulation no 33/2008 about standard of special schools. Later on the regulation being simplified into guideline criterion tables, so it can be more convinient in evaluating the special schools in the future. The result of this evaluation is SLB Negeri Semarang has failed to some education facilities standard especially in student and teacher communal spaces.

\section{Methods}

Literatures study and cases study were used as research methods. Evaluation study main power is the set of evaluation sheet which later on being baseline in evaluating the objects $[14,15,16]$. This study carries the main literatures of Indonesia education facilities standards (Permendiknas no 33/2008) which being modified to be more operational friendly for evaluation researches. Furthermore, the constructed evaluation sheet will be assessed to physical aspect on SLB Negeri Ungaran case studies in Indonesia.

The evaluation consists of two main parameters of the availability and the space standard. The parameters were closely related to universal design principle of safety, supportive, adaptability and accessibility [17]. The available items were describing the basic effort in understanding the space requirements (safety and supportive) about the special education facilities. Furthermore, the space standard showed the adaptability and accessibility efforts of the school to meet the special needs educations.

\section{Results and discussion}

\subsection{The Regulation of Special School}

Special School is a school for special needs and diffable students with a special curriculum and facilities which being provided to support the students [18]. According to the verse 32 (1) of National system of education no 20/2003, the Special schools (SLB) have 4 type of special education criteria, such as:

1. SLB A, for visual disabilities students

2. SLB B, for audial disabilities students

3. SLB C, for mental disabilities students (in degree of illness, $\mathrm{C} 1$ for the severe and C2 for the light)

4. SLB D, for the handicapped movement disabilities students

As mentioned before this SLB is having special curriculum which different from the national one. The main subject of religion, sciences, social sciences, civic, languages, 
mathematics, arts and sports in this SLB still being taught by the teachers and the special subjects of orientation-mobilities, communication-sound, movement developments, and selfimprovement are also being educated for the students.

The physical requirement has been set by the ministry of education in their decree and local government rules to bring a good facility of SLB according to the students' quantity and the curriculum. From the standard we can assumed the minimum requirements as described in table 1 below. Later on, this evaluation sheet become the base in SLB Negeri Ungaran examination.

Table 1. Special school facilities

\begin{tabular}{|c|c|c|}
\hline No & Facilities & Minimum standards \\
\hline 1 & Class & $3 \mathrm{~m} 2 /$ student \\
\hline 2 & Library & $30 \mathrm{~m} 2$ \\
\hline 3 & Orientation-Mobilities class & $15 \mathrm{~m} 2$ \\
\hline 4 & Communication class & $4 \mathrm{~m} 2$ \\
\hline 5 & Sound class & $30 \mathrm{~m} 2$ \\
\hline 6 & Self-improvement class & $24 \mathrm{~m} 2$ \\
\hline 7 & Movement class & $30 \mathrm{~m} 2$ \\
\hline 8 & Art class & $24 \mathrm{~m} 2$ \\
\hline 9 & Wooden art class & $24 \mathrm{~m} 2$ \\
\hline 10 & Ceramic art class & $24 \mathrm{~m} 2$ \\
\hline 12 & Workshop & $24 \mathrm{~m} 2$ \\
\hline 13 & Sewing class & $24 \mathrm{~m} 2$ \\
\hline 14 & Computer class & $24 \mathrm{~m} 2$ \\
\hline 15 & Kitchen & As demand \\
\hline 16 & Painting class & $24 \mathrm{~m} 2$ \\
\hline 17 & Music class & $24 \mathrm{~m} 2$ \\
\hline 18 & Dancing class & $24 \mathrm{~m} 2$ \\
\hline 19 & Parlour class & $24 \mathrm{~m} 2$ \\
\hline 20 & Crafting class & $24 \mathrm{~m} 2$ \\
\hline 21 & Exhibition room & $24 \mathrm{~m} 2$ \\
\hline 22 & Hall & As demand \\
\hline 23 & Archery class & As demand \\
\hline 24 & Swimming pools & As demand \\
\hline 25 & Head master room & $12 \mathrm{~m} 2$ \\
\hline 26 & Teacher room & $4 \mathrm{~m} 2 /$ teacher \\
\hline 27 & Administration room & $4 \mathrm{~m} 2 / \mathrm{staff}$ \\
\hline 29 & Worshiping space & $12 \mathrm{~m} 2$ \\
\hline 30 & Healthcare & $12 \mathrm{~m} 2$ \\
\hline 31 & Consultation room & $9 \mathrm{~m} 2$ \\
\hline 32 & Student welfare room & $9 \mathrm{~m} 2$ \\
\hline 33 & Toilet & $2 \mathrm{~m} 2 /$ unit \\
\hline 34 & Storages & $18 \mathrm{~m} 2$ \\
\hline 35 & Circulation space & $30 \%$ of area \\
\hline 36 & Sports & as demand \\
\hline
\end{tabular}




\subsection{Briefs of SLB Negeri Ungaran (Study Case)}

Special School of SLB Negeri Ungaran is located on J1 Kyai Sono 2, Genuk, Kec. Ungaran Barat, Kab. Semarang Prov. Jawa Tengah as described on the picture 1. It has $9983 \mathrm{~m} 2$ area, since 1983 and has B accreditation. The site has boundary of north: SMP N 1 Ungaran, east: RSUD Ungaran, South : Hotel Melati Serba Dua and west: Watu Lumpang swimming pools (see figure 2). The condition of rural-urban area still related to the SLB environments and potential to be next development of school areas.

Current situation of 2020, SLB Negeri Ungaran is having class (students), as : TKLB A (3), TKLB B (8), TKLB C (5), SDLB A (2), SDLB B (30), SDLB C (15), SDLB C1 (38), SDLB D (9), SDLB Q (6), SMPLB (56), SMALB (43) and having supporting teachers 34 in total. Therefore, the capacity of the SLB Negeri shall meet the space requirement of these users.

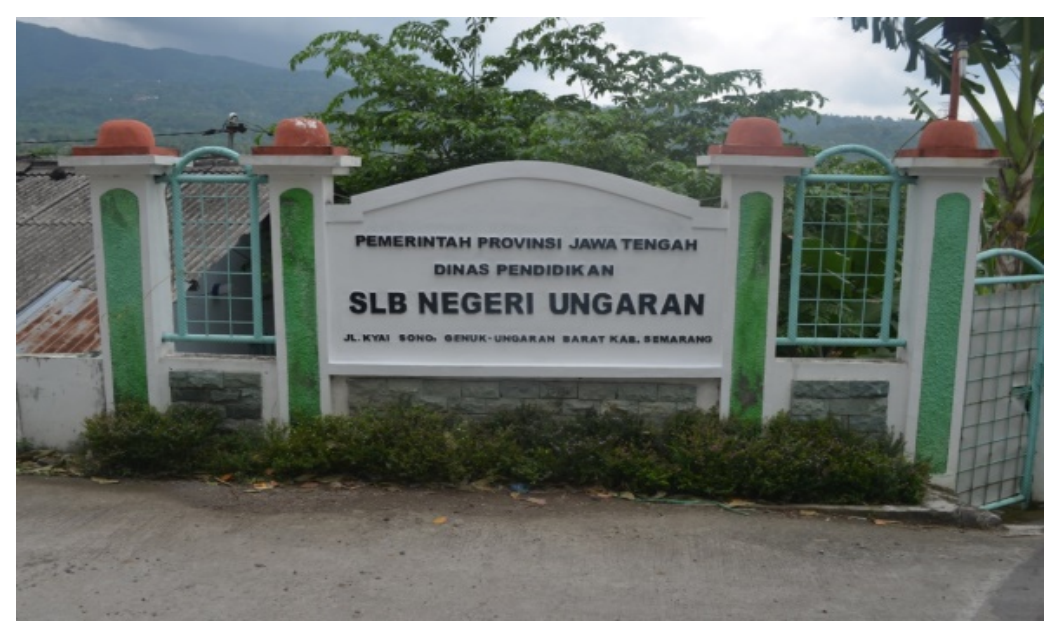

Fig. 1. The locator of SLB Negeri Ungaran

The street of Kyai Sono is wide enough to be accessed by cars and buses. That condition supported SLB Negeri Ungaran for the environment connectivity and near this site there also a Vocational School (SMK) Kanaan and District office Kantor Kelurahan Genuk for the social facilities (see figure 2). This area land use is blue colour or dedicated for social and public facilities area of Ungaran regency, so the urban network also connected to this area. 


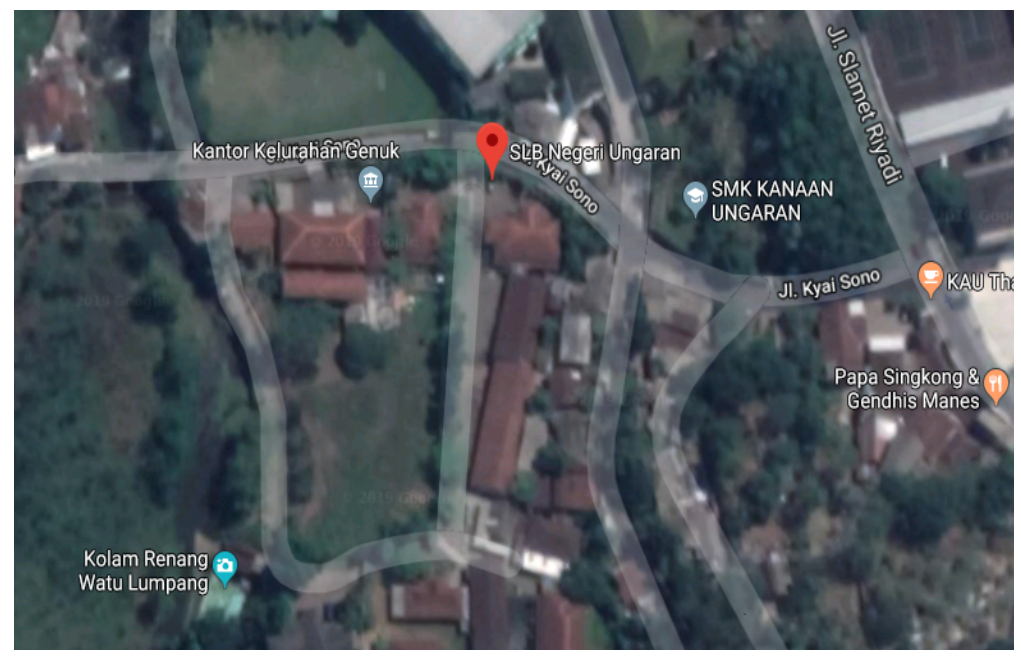

Fig. 2. The map of SLB Negeri Ungaran (source: google map view)

This SLB Negeri Ungaran is consist of several buildings or considered as multi building for education purpose. The main 8 buildings are office, exhibition room, class, art class, mushola, canteen, dormitory, and multifunction room (see figure 3 ). The buildings are connected by landscape design and corridors. The site shape is quite irregular with narrow front side and wider rear side just like pocket plot. This condition is related to the government land on the site that need to be separated into several divisions.

Despite irregular site of the SLB Negeri Ungaran, the design of this school was attached on the grid order with street/connector orientation. The front side of the site is the place for the office and exhibition, and the remains spaces are located on the rear side (see figure 3 ).

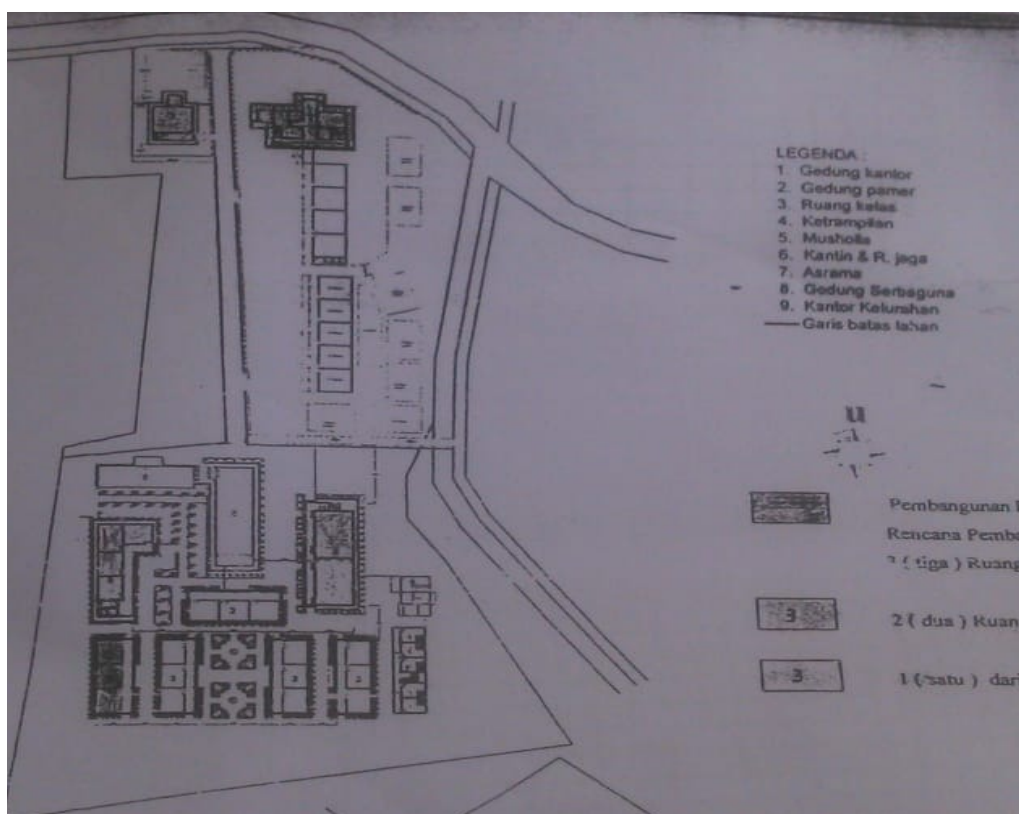

Fig. 3. The Siteplan of SLB Negeri Ungaran (Source: SLB Negeri Ungaran documents) 


\subsection{Evaluation Results}

There are three main type of spaces in this SLB Negeri Ungaran, such as: offices, classes and therapy rooms. The offices are consisting of the head master, administration and teacher office. The classes were divided into TKLB (kindergarten), SDLB (elementary), SMPLB (junior high school) and SMALB (senior high school). The Therapy rooms are OrientationMovement room, sound room, consultation room and healthcare. The remain supporting room such as: library, storage, toilet, worshiping (mushola), sport and student welfare room were built to support the main education activity of this SLB (see table 2). The main three type of space, later on being the structured descriptive analysis to examine and evaluate the physical condition of this SLB Negeri Ungaran.

Table 2. SLB Negeri Ungaran evaluation results

\begin{tabular}{|c|c|c|c|c|c|}
\hline No. & Facilities & availability & count & $\begin{array}{l}\text { Standard } \\
\text { area }(\mathrm{m} 2)\end{array}$ & $\begin{array}{l}\text { Existing } \\
\text { area }\end{array}$ \\
\hline 1 & TKLB Class & $\mathrm{V}$ & 3 & $12 \mathrm{~m} 2$ & $20 \mathrm{~m} 2$ \\
\hline 2 & SDLB Class & $\mathrm{v}$ & 36 & 15 & 16 \\
\hline 3 & SMPLB Class & $\mathrm{V}$ & 18 & 15 & 20 \\
\hline 4 & SMALB Class & $\mathrm{v}$ & 15 & 15 & 20 \\
\hline 5 & Library & $\mathrm{V}$ & 2 & 30 & 32 \\
\hline 6 & $\begin{array}{c}\text { Orientation } \\
\text { Mobility room }\end{array}$ & - & - & - & - \\
\hline 7 & Movement therapy & - & - & - & - \\
\hline 8 & $\begin{array}{l}\text { Self-Development } \\
\text { space }\end{array}$ & - & - & - & - \\
\hline 9 & Sound therapy & $\mathrm{V}$ & 1 & 4 & 20 \\
\hline 10 & Headmaster office & $\mathrm{V}$ & 1 & 12 & 12 \\
\hline 11 & Teacher room & $\mathrm{v}$ & 1 & $\begin{array}{c}\text { 4/teacher } \\
(4 \times 34=136)\end{array}$ & 72 \\
\hline 12 & $\begin{array}{l}\text { Administration } \\
\text { room }\end{array}$ & $\mathrm{V}$ & 1 & $\begin{array}{c}4 / \text { staff } \\
(4 \times 4=16)\end{array}$ & 20 \\
\hline 13 & Worshipping place & - & - & - & - \\
\hline 14 & Health care & $\mathrm{V}$ & 1 & 12 & 16 \\
\hline 15 & Consultation room & $\mathrm{V}$ & 1 & 9 & 12 \\
\hline 16 & Toilet & $\mathrm{V}$ & 4 & 2 & 3 \\
\hline 17 & Storage & $\mathrm{V}$ & 2 & 18 & 20 \\
\hline 18 & Sport room & $\mathrm{V}$ & 1 & 200 & 96 \\
\hline 19 & Circulation space & $\mathrm{V}$ & & $\begin{array}{c}30 \% \text { total } \\
\text { area } \\
(30 \% \times 9983 \\
=2994.9)\end{array}$ & \pm 3000 \\
\hline 20 & Student welfare & - & - & - & - \\
\hline
\end{tabular}

Related to the evaluation table 2 above, there are several facilities that has been designed and well capacity. The classes were well designed and built as shown that all of it are fulfilled the standards. From this condition, we can assume that this SLB orientation is for the basic class requirements, since all of the class has met the mandatory regulation.

In other hand, the therapy rooms were not well provided by the SLB. It shown on the absences of OM room and movement therapy. However, the presence of sound room, consultation room and health care in this SLB is still well designed. These conditions may assume as this school is closely related to SBL type B for audial disabilities students. 
The absences of in site worshiping place, lack of sport room and library has brought low result in this facilities evaluation based on the Permendiknas. The worshiping place of this SLB is shared with Kantor Kelurahan's Mushola as mentioned on the previous map. Sport room also shared with the kelurahan soccer field and the library is still below the standards.

In historical background, this SLB Negeri Ungaran was a special school for the deaf students or type B only. So, the facilities of audial disabilities were already existed before the built of this SLB. The previous tales also mentioned that this site is government land which being separated into several division, so the sport and religion worshiping facilities are shared with other government unit in this area. Furthermore, these conditions were happened because the development of rural into rurban area of Ungaran regency is still on process.

In the future the improvement of the SLB facilities still can be performed with vacant land spot near this site. This research also can be a guideline for further correction and improvement to make this SLB Negeri Ungaran become better special school for many types of disabilities students and community.

\section{Conclussion}

The result of this research shown that most of the mandatory space already being built but the details were not designed as the standards. The development of special school was related to previous function of the school and the condition of the surroundings. Further development of special school (SLB) shall follow the basic regulation of Permendiknas no 33/2008 about Indonesia education facilities standards.

\section{References}

1. _... Indonesia State Constitution 1945 verse 31 (1) (1945)

2. ___. Constitution no. 20/2003 about National Education System (2003)

3. https://www.kemdikbud.go.id/main/blog/2017/02/sekolah-inklusi-dan-pembangunanslb-dukung-pendidikan-inklusi accessed on february 2020

4. Maulipaksi, D. Sekolah Inklusi dan Pembangunan SLB Dukung Pendidikan Inklusi. Jakarta: Kemendikbud (2017)

5. https://bulelengkab.go.id/assets/instansikab/126/bankdata/kementerian-sosial-dalamrangka-pembangunan-kesejahteraan-sosial-th-2012-57.pdf accessed on february 2020

6. https://media.neliti.com/media/publications/104646-ID-peran-dinas-pendidikan-dankebudayaan-pr.pdf accessed on february 2020

7. M. Paristiawan, A. Taufiq, and P. ., "Peran Dinas Pendidikan dan Kebudayaan Provinsi Jawa Tengah dalam Pengembangan Sekolah Luar Biasa (SLB) di Semarang," Journal of Politic and Government Studies, vol. 6, no. 03, pp. 411-420 (2017)

8. Indonesia, A. Terbatas, Daya Tampng Sekolah Luar Biasa. Indonesia: Education News Monitoring Service (2017)

9. Soleh, A. Aksesibilitas Penyandang Disabilitas terhadap Perguruan Tinggi.

Yogyakarta: PT. LKiS Printing Cemerlang (2016)

10. Susilawati, D. Indonesia Miliki 12 Persen Penyandang Disabilitas. Jakarta: Republika. (2016).

11. Tuslina, T. Perkembangan Pendidikan Anak Berkebutuhan Khusus di Indonesia (2012) 
Retrieved 09 05, 2017, from Kompasiana.com:

http://www.kompasiana.com/tanamilmu/perkembangan-pendidikan-anakberkebutuhan-khusus-di-indonesia_55107ad1a33311273bba8243

12. Yani, A. A. Kelalaian Negara Memenuhi Hak Warga Difabel. Makassar: Tribun Timur (2013)

13. Indonesia Minister of Education and Culture (2008) Minister of Education and Culture no 3 th 2008 about Inclusive Education Process Standard

14. Harsritanto, B. I. Sustainable Streetscape Design Guideline based on Universal Design Principles. MATEC Web of Conferences 159 (2018)

15. BIR, Harsritanto. E3S Web of Conferences 31, 09010 (2018)

16. Bangun IR Harsritanto, Indriastjario, Wijayanti. Universal design characteristic on themed street, IOP Conf. Series: Earth and Environmental Science 99012025 (2017)

17. B I R Harsritanto et al. IOP Conf. Ser.: Earth Environ. Sci. 313012028 (2019) 